Diabetologia 10, 233-236 (1974)

(C) by Springer-Verlag 1974

\title{
Serum Levels of Insulin-Binding Antibodies in Diabetic Patients Treated with Monocomponent Insulin
}

\author{
A. Czyżyk, J. Ławecki, H. Rogala, E. Miedzińska and A. Popik-Hankiewicz \\ Department III of Internal Diseases, Medical Academy, Warsaw, Poland
}

Received: November 26, 1973, and in revised form: February 26, 1974

Summary. Levels of insulin binding immunoglobulin $\mathrm{G}(\mathrm{IgG})$ were determined by the method of Christiansen in diabetic patients divided into the following groups: 1 . recently diagnosed diabetics, treated from the beginning with monocomponent (MC) pork insulin (12 patients); 2. diabetics treated from the beginning with several times recrystallized monospecies (MS) pork insulin (6 patients), and 3. diabetics previously treated for long periods with commercial insulin and changed to MC pork insulin (11 patients). The patients were observed for periods of from several months to two years. In patients treated with MC insulin, levels of insulin antibodies in the serum were not significantly increased, except in 3 patients who had viral hepatitis before or during insulin therapy and in an other patient immediately after an attack of influenza. In a majority of the patients treated with MS insulin, an in. crease in levels of insulin antibodies in the serum was ob. served. Patients previously treated with commercial in- sulin had very high titers of insulin antibodies in their serum, which decreased after changing over to MC insulin. In this group, some patients, in spite of continuation of treatment with MC insulin, developed increasing levels of insulin-binding antibodies in the serum during a later period of observation.

The results indicate that during treatment of diabetes with insulin, contaminating pancreatic proteins due to shortcomings in production technology are responsible for immunogenicity of the insulin preparations. However, immunogenic properties of pure insulin may become manifest under clinical conditions in patients whose immune system has been sensitized by different factors.

Key words: Insulin antibodies, insulin therapy, monocomponent insulin, immunoelectrophoresis, diabetes, virus hepatitis.
It has been reported that treatment with monocomponent insulin did not induce insulin antibodies, or only to a small degree in comparison with insulin of conventional purity $[1-4]$.

The studies reported in this paper on the influence of commercially available insulin, of several times recrystallized monospecies pork insulin and of monocomponent pork insulin on the levels of insulin-binding antibodies in the blood serum of diabetic patients, indicate, that besides the degree of purification of insulin the production of insulin antibodies may also depend on other factors, modifying the immunoreactivity of the human organism.

\section{Patient Material and Methods}

Observations were made on 29 diabetic patients followed for periods of 6 months to 2 years. The patients were divided into three groups:

1. Patients with recently diagnosed diabetes requiring insulin, treated from the beginning with monocomponent (MC) insulin, at first with rapidly acting pork insulin (Actrapid $\mathrm{MC}^{\circledR}$ or Semilente $\mathrm{MC}{ }^{\circledR}$ ), and, after control of carbohydrate metabolism, with MC pork insulin Lente (Monotard ${ }^{\circledR}$ ). This group consisted of 12 patients ( 8 men and 4 women) aged $14-51$ years, including 11 with normal body-weight and 1 obese patient. The period of observation of these patients was from 6 to 23 months.
2. Patients with recently diagnosed diabetes requiring insulin, treated from the beginning with several times recrystallized, monospecies (MS) pork insulin. Like the patients of the preceding group, they were treated at first, as long as their diabetes was not stabilized, with rapid acting insulin (Actrapid MS and Semilente MS). This group consisted of 6 patients (men) aged 22-40 years with normal body-weight, who were observed for 8-16 months.

3. Patients with diabetes of longer standing, treated previously with commercial insulin Lente ${ }^{\circledR}$, who were changed over to MC pork insulin Monotard ${ }^{\circledR}$. This group consisted of 11 patients $(7$ men and 4 women) aged $32-75$ years. The period of previous treatment with commercial insulin was from 10 months to 7 years (cf. Table 1), and the period of observation during treatment with MC insulin was 10 to 13 months.

The group 1 and group 2 patients were admitted to the department immediately after diagnosis of diabetes. After stabilization of their diabetes, their daily insulin requirements were determined under the control of $24 \mathrm{~h}$ glycemia and glycosuria. The ocular fundus was examined, renal function was determined, neurologic examinations were made, tests of the blood supply to the extremities and electrocardiograms were performed. Patients with allergic symptoms, hormonal and metabolic disorders other than diabetes were excluded from further observation. Group 3 patients were examined in the same way at the Out-Patient Clinic for Diabetics. 


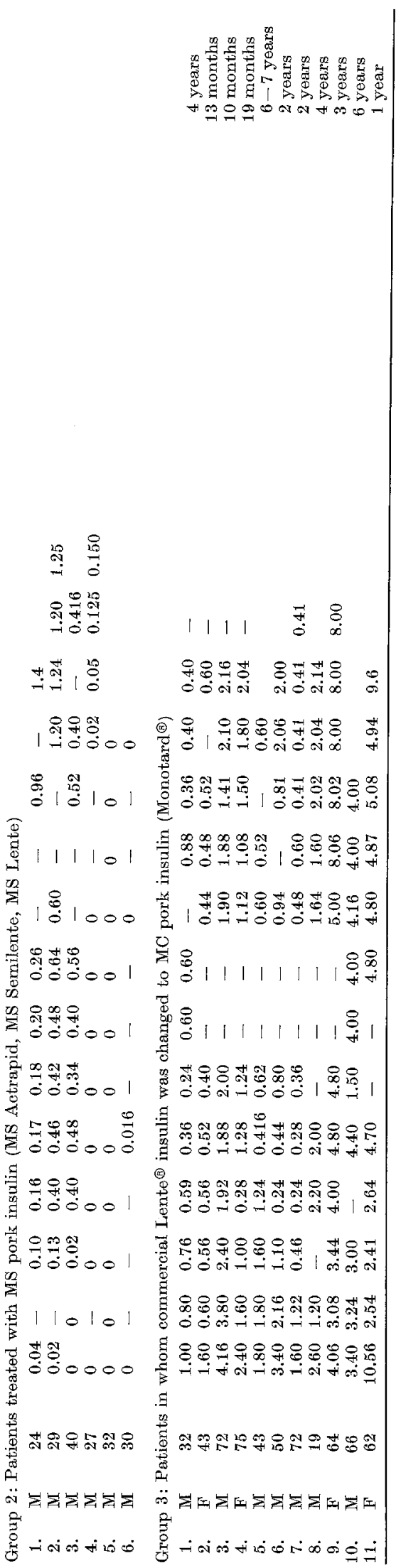


Observations of all the patients were continued at the Out-Patient Clinic at intervals of about one month, on the average. All the Novo insulin preparations were pork insulins, but the commercial preparation received by group 3 patients before changing over to $\mathrm{MC}$ insulin was a beef/pork insulin. The group 1 and 2 patients received disposable syringes.

Insulin-binding antibodies in the blood serum were assayed by the method of Christiansen [5] employing immuno-electrophoresis in agar gel, based on binding

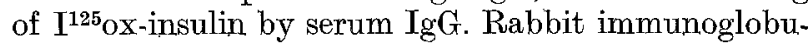
lins to human IgG, Dakopatts, Denmark, were used. In previously untreated persons, binding of insulin labeled with radioiodine did not exceed $0.05 \mathrm{mU} / \mathrm{ml}$ of serum. MC insulins, MS insulins, commercial insulin and $\mathrm{I}^{125} \mathrm{Ox}$-insulin $(20-25 \mathrm{mU} / \mathrm{ml}$, spec. activity ca. $20 \mathrm{mC} / \mathrm{mg}$ ) were supplied by Novo Research Institute.

\section{Results}

Table 1 gives the results of assays of insulin antibodies in the sera of 9 out of 12 patients in group 1 . Two patients (patient K.B. and R.J.) contracted virus hepatitis during the observation period, but continued treatment with MC insulin. In these patients serum levels of insulin antibodies behaved differently, increasing to maximal concentrations of $0.260 \mathrm{mU} / \mathrm{ml}$ and $0.156 \mathrm{mU} / \mathrm{ml}$ (cf. Fig. 1). In the third patient (B.J.) treatment of recently diagnosed diabetes with MC insulin was begun several weeks after virus hepatitis; after nine months on this treatment, the serum level of insulin antibodies was $0.100 \mathrm{mU} / \mathrm{ml}$ (cf. Fig. 1). In 8 of the 9 patients in Table 1, serum levels of insulinbinding antibodies showed no increase throughout the period of observation. In one patient (case 5) after 10 months, the serum antibody levels increased distinctly shortly after he had influenza; at the same time

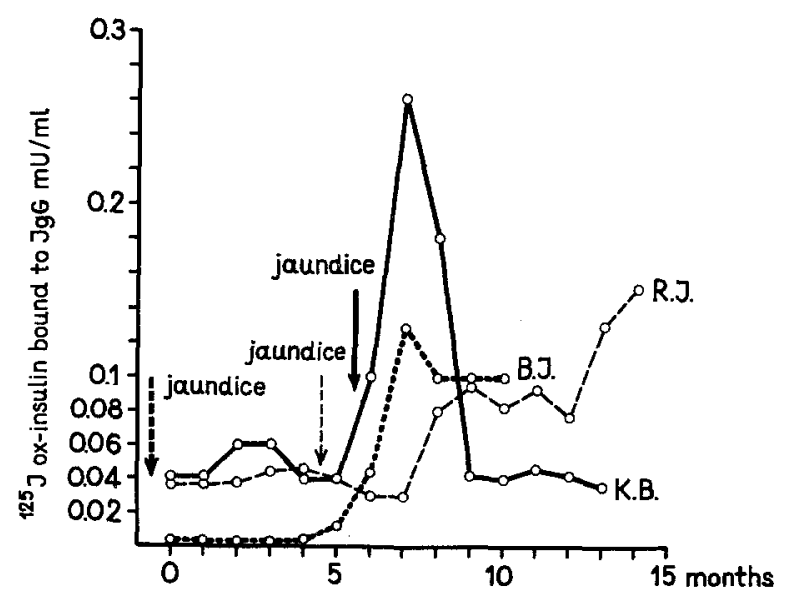

Fig. 1. Behaviour of insulin-binding antibodies in the blood serum of three adult diabetics treated with MC pork insulin Actrapid, Semilente and Lente (Monotard $\odot$ ), who developed virus hepatitis prior to or during the observation period the $24 \mathrm{~h}$ requirement of insulin increased. The mean $24 \mathrm{~h}$ requirement of insulin in this group of patients was 37.6 units in the initial period and 26.8 units during the terminal period of observation.

In two patients in group 2, insulin-binding antibodies in the serum increased within 2-3 months after the beginning of administration of MS pork insulin, and the rising tendency continued during further observation. In one patient, a significant increase in concentration of insulin antibodies in the serum appeared in the third month of treatment and continued at this level until the end of the observation period (14. months). In three other patients, no significant increase in insulin-binding antibodies occurred during a years' observation, but in one of these patients a rise occurred in the 13 th and 14 th months of observation (cf. Table 1). The mean $24 \mathrm{~h}$ requirement for insulin in this group of patients was 41.6 units in the initial period of treatment and 26 units during the remainder of the observation period.

In patients treated with commercial insulin (group 3), levels of insulin-binding antibodies in the serum were very high in all cases $(1.00-10.55 \mathrm{mU} / \mathrm{ml})$, this possibly resulting not only from the lower degree of purity of commercial insulin, but also from the species difference (beef insulin is known to be more immunogenic in humans than pork insulin) and perhaps from the duration of treatment which in the major proportion of cases was longer than that of MC insulin therapy. This high serum level of insulin-binding antibodies dropped after the change-over to MC insulin. In the majority of cases (in 9 patients), a drop was noted after one month of treatment with MC insulin, and the maximum drop after $3-5$ months of treatment with this insulin (cf. Table 1). Later during the observation. period, the insulin antibody titers increased again. In 6 patients the titers were low, but in 4 attained levels similar to the starting ones after 12 months. In one patient, after a slight initial drop in the level of serum insulin antibodies, titers increased attaining twice the starting level after 9 months' treatment with $\mathrm{MC}$ insulin. There was no correlation between the recurrence of high serum insulin antibody level, and the duration of treatment with commercial insulin, and insulin antibody level before the change from commercial in. sulin to MC insulin.

The mean requirement of insulin immediately after the change from commercial to MC insulin was 38.1 units and, after one year on MC insulin, 36.9 units.

\section{Discussion}

The study results indicate that the immunogenicity of insulin used in the treatment of diabetes, measured on the basis of levels of insulin binding to $\operatorname{IgG}$ may depend on contaminating pancreatic proteins not removed by hitherto known production methods. The highest concentrations of insulin antibodies were ob- 
served in patients treated with commercial insulin, lower concentrations were seen after injections of MS insulin, and practically no detectable antibodies were observed in patients treated with MC insulin. However, the reported observations indicate that in certain situations the immunogenic action of $\mathrm{MC}$ insulin may be enhanced. The patients who had virus hepatitis before or during treatment with monocomponent insulin, and in whom high titers of insulin-binding antibodies were observed during the disease, deserve notice, as does the patient in whom a sudden and considerable rise in antibodies occurred during the 10 th month of treatment with $\mathrm{MC}$ insulin immediately after an attack of influenza. It is possible that in these patients virus infection altered the reaction of the immune apparatus. The damage of the liver by virus hepatitis has been shown to increase the antibody production [6]. Also bacteria and bacterial products were found to have an adjuvant effect to the injection of antigen (of. 7). The behaviour of the insulin antibody levels in the serum after change from commercial to MC insulin is another example. As a rule, the change caused a decrease of serum antibodies. In most cases, they later rose to the previous or even higher levels. The mechanism of this phenomenon is not clear, but it is likely that prolonged treatment with commercial insulin sensitizes the immune system of the organism to this hormone, so that treatment with $\mathrm{MC}$ insulin may cause the appearance of insulin antibodies in the blood in concentrations exceeding the threshold value.

Acknowledgement. We are grateful to Dr. J. Schlicht. krull of the Novo Research Institute for supplying the MC and MS insulins, reagents and apparatus used in this study.

\section{References}

1. Schlichtkrull, J., Brange, J., Christiansen, Aa. H., Hallund, O., Heding, J.G., Jørgensen, K.H.: Clinical aspects of insulin-antigenicity. Diabetes 21, Suppl. 2, $649-656(1972)$

2. Fankhauser, S., Michl, J.: Zwei Jahre Erfahrungen mit Monocomponent-Insulin bei Diabetikern. In: 3 . Internationales Donau-Symposium über Diabetes mellitus. 43-47, (Herausg. Beringer, A.). Wien-MünchenBern: Maudrich 1973

3. Korp, W., Levett, R.E.: Erfahrungen mit Monokomponenteninsulin. Wien. klin. Wschr. 85, 326-330 (1973)

4. Bruni, B., D'Alberto, M., Osenda, M., Ricei, C., Turco, G.L.: Clinical trial with monocomponent lente insulins. Preliminary report. Diabetologia 9, 492-498 (1973)

5. Christiansen, Aa.H.: Radioimmunoelectrophoresis in the determination of insulin binding to IgG. Methodological studies. Horm. Metab. Res. 5, 147-154 (1973)

6. Havens, W.P., Jr.: Liver disease and antibody formation. Int. Arch. Allergy 14, $75-83$ (1959)

7. Munoz, J.: Effect of bacteria and bacterial products on antibody response. In: Advances in immunology. Vol. 4, 397-440, (Eds. Dixon, F.J., Jr., Humphrey, J.H.). New York-London: Academic Press 1964

Prof. Dr. Artur Czyżyk

Department III of Internal Diseases

Medical Academy Warsaw

ul. Lindleya 4

P-02-005 Warszawa

Poland 